\title{
Радиационные донорные дефекты в имплантированных As пленках МЛЭ CdHgТe: пространственное распределение и природа
}

\author{
А.Г. Коротаев ${ }^{1)}$, И.И. Ижнин ${ }^{1,2)}$, Е.И. Фицыч ${ }^{2)}$, А.В. Войцеховский(), К.Д. Мынбаев ${ }^{3,4)}$, В.С. Варавин ${ }^{5)}$, \\ С.А. Дворецкий ${ }^{1,5)}$, Н.Н. Михайлов ${ }^{5)}$, В.Г. Ремесник ${ }^{5)}$, М.В. Якушев ${ }^{5)}$, О.Ю. Бончик ${ }^{6)}$, Г.В. Савицкий6), \\ Y. Morgiel ${ }^{7)}$, Z. Świątek ${ }^{7)}$ \\ ${ }^{1}$ Национальный исследовательский Томский госуниверситет, Томск, 634050, Ленина 36 \\ ${ }^{2}$ Научно-производственное предприятие «Электрон-Карат», Львов, 79031, Стрийская 202 \\ ${ }^{3}$ ФТИ им. А.Ф. Иоффе, Санкт-Петербург, 194021, Политехническая 26 \\ ${ }^{4}$ Университет ИТМО, Санкт-Петербург, 197101, Кронверкский 49 \\ ${ }^{5}$ ИФП им. А.В. Ржанова СО РАН, Новосибирск, 630090, ак. Лаврентьева 13 \\ ${ }^{6}$ ИППММ им. Я.С. Пидстригача НАН Украины, Львов, 79060, Научная $3 б$ \\ ${ }^{7}$ Institute of Metallurgy and Material Science PAN, 30-059, Krakow, Reymonta, 25 \\ тел:+7(3822) 412-573, факс:+7(3822) 412-573, эл. почта: kor@mail.tsu.ru
}

DOI 10.34077/RCSP2019-57

Несмотря на многочисленные работы по исследованию радиационных дефектов в подвергнутых ионной имплантации твердых растворах $\mathrm{Cd}_{\mathrm{x}} \mathrm{Hg}_{1-\mathrm{x}} \mathrm{Te}$, вопрос о пространственной локализации и природе донорных радиационных дефектов остается открытым даже для хорошо изученного случая имплантации ионов $\mathrm{B}^{+}$. По нашему мнению это связано с многочастичным спектром носителей заряда в радиационно-модифицированной области материала, когда для определения профилей распределения носителей каждого типа необходимо использовать соответствующие методы анализа результатов дифференциального эффекта Холла. Кроме того, необходимо также дополнительно исследовать дефектную структуру радиационно-нарушенной области.

В работе представлены результаты комплексных исследований радиационных дефектов в имплантированных $\mathrm{As}$ гетероэпитаксиальных структурах $\mathrm{Cd}_{\mathrm{x}} \mathrm{Hg}_{1-\mathrm{x}} \mathrm{Te}$ (ГЭС КРТ), полученных методом молекулярно-лучевой эпитаксии (МЛЭ) на подложках $\mathrm{Si}$ (GaAs) в ИФП СО РАН. Исследовали ГЭС $p$-типа проводимости с сохраненным и удаленным варизонным защитным слоем после имплантации ионов $\mathrm{As}^{+}$с энергией 190 кэВ и дозой в $10^{15} \mathrm{~cm}^{-2}$, в результате которой были получены типичные $n^{+}-n-p$ структуры с радиационно-модифицированной $n^{+}-n$-областью. Пространственное распределение носителей исследовали при послойном химическом травлении с измерением полевых зависимостей коэффициента Холла $R_{H}(B)$ и проводимости $\sigma(B)$ и их анализа методом дискретных спектров подвижности. Дополнительно использовались данные вторичной ионной масс-спектроскопии (ВИМС), просвечивающей электронной микроскопии в режиме светлого поля и высокого разрешения и литературные данные профилей дефектов, полученных из спектров резерфордовского обратного рассеяния.

В радиационно-модифицированной $n+-n-$ области структуры обнаружены три типа электронов с различной подвижностью, обусловленные соответствующими донорными дефектами, локализованными на различных глубинах радиационно-нарушенного слоя структуры: а) электроны с низкой подвижностью порядка $\sim 5000 \mathrm{~cm}^{2} /(\mathrm{B} \cdot \mathrm{c})$ локализованы в приповерхностном $n^{+}$-слое толщиной $\sim 400$ нм, в области присутствия крупных и мелких дислокационных петель. Предполагаемая природа донорного центра, обуславливающего наличие электронов с низкой подвижностью - междоузельная ртуть, захваченная дислокационной петлей; б) электроны с промежуточной подвижностью 20000 $\mathrm{cm}^{2} /(\mathrm{B} \cdot \mathrm{c})$ локализованы также в $n^{+}$-слое толщиной до $\sim 700-900$ нм в области существования квазиточечных радиационных дефектов. Предполагаемая природа донорных дефектов - комплексы междоузельной ртути с этими квазиточечными дефектами; в) электроны с высокой подвижностью $\sim 90000 \mathrm{~cm}^{2} /(\mathrm{B} \cdot \mathrm{c})$ локализованы в $n$-слое $n^{+}-n-p$ структуры на глубине более $700-900$ нм. Механизм формирования этой области хорошо известен и связан с диффузией междоузельной ртути, генерируемой при имплантации, и ее аннигиляцией с вакансиями ртути в исходной области $p$-типа. 